\title{
Warisan Islam Nusantara
}

\author{
Zakiya Darajat ${ }^{1}$
}

\begin{abstract}
Abstrak
Di tengah perbenturan dua arus utama yang saling tarik menarik antara arus sekulerisme-liberal Barat dan arus fundamentalisme-radikal Timur Tengah, Islam Nusantara-dengan berbagai macam karakteristiknya-berhasil mempertahankan warna kemoderatannya. Sikap mengambil jalan tengah dalam segala dimensi kehidupan keberagamaan sangat selaras dengan watak dan karakteristik umat Islam Indonesia yang sangat fleksibel, toleran dan terbuka dalam menerima dan mensikapi segala perbedaan tradisi, pandangan dan keyakinan keberagamaan, sehingga melahirkan kearifan lokal (local wisdom), serta corak dan warna Islam Nusantara yang sangat khas, berupa Islam yang ramah, toleran, dan pluralistik. Karakteristik Islam Indonesia yang toleran, ramah, smiling, dan flowering ini bukanlah sesuatu yang muncul tiba-tiba, akan tetapi merupakan hasil sebuah proses panjang yang telah dilalui umat Islam Indonesia, menyangkut profil para tokoh pendakwah Islam, metode yang digunakan dalam penyebaran Islam di Nusantara, sarana dan media penyebaran Islam, juga relasinya dengan kekuasaan politik. Beberapa hal inilah yang turut mempengaruhi begitu kokohnya warna moderatisme Islam di Nusantara. Kini, Islam Nusantara telah banyak melahirkan warisan peradaban sebagai harta peninggalan yang tak ternilai harganya, sekaligus sebagai bukti otentik betapa Islam telah ikut memberi corak dan warna bagi kemajuan peradaban masyarakat Muslim Indonesia maupun dunia.
\end{abstract}

Kata Kunci: Islam Moderat, Kearifan Lokal, Warisan Peradaban Nusantara.

\begin{abstract}
In the midst of the clash between two mainstreams; 'liberal-secularism' of the West mainstream and radical-fundamentalism of Middle East mainstream, Islam Nusantara - with its various characteristics - managed to maintain its moderate color. The attitude to choose moderate way in every dimension of religious life is in line with the nature and characteristics of Indonesian muslim community which is flexible, tolerant, and open minded to receive and respond with the various of traditions, views, and religion belief to create local wisdom, characteritistics, and the distinctive type of Islam Nusantara that shows friendly, tolerant, and pluralistic Islam. The characteristics of Indonesian muslims which are tolerant, friendly, smiling, and flowering do not suddenly appear, but it is the result of a long process experienced by Indonesian muslim community, including the profile of Islamic figures, method used to spread Islam in Nusantara, infrastructure and media of spreading Islam, and its relation with political power. These factors influence the strength of moderation of Islam in Nusantara. Currently, Islam Nusantara has created civilization heritage as precious inheritance, as well as authentic evidence showing that Islam has contributed to the civilization progress of Indonesian muslim community specifically, and the world population generally.
\end{abstract}

Keywords: Moderate Islam, Local Wisdom, Nusantara Civilization Heritage.

\footnotetext{
${ }^{1}$ Mata Kuliah Umum (MKU) dan Ilmu Agama Islam (IAI) Universitas Negeri Jakarta.
} 


\section{A. Pendahuluan}

Dalam kesempatan perkuliahan yang penulis ikuti di Sekolah Pascasarjana UIN Jakarta mata kuliah History of Southeast Asian Islam; Social Intellectual, ${ }^{2}$ Guru Besar Sejarah Islam UIN Jakarta Prof. Dr. Azyumardi Azra, MA mengemukakan bahwa wilayah peradaban Islam terbagi atas delapan cultural domain (sphere).

Pertama adalah Arabic cultural domain, yang memiliki banyak tradisi dan kabilah tetapi memiliki bahasa yang sama, yaitu Bahasa Arab. Kedua adalah Iranian-Persian Islamic cultural sphere yang memiliki tradisi intelektual Persia yang sangat kuat. Ketiga adalah Turkish Islamic cultural sphere, yang menekankan tradisi ghazi (kewiraan, militerisme), tidak terlalu filosofis, hingga Turki bisa menguasai Eropa. ${ }^{3}$ Keempat adalah Sudanic Islamic cultural sphere, yang memiliki orientasi tradisi lokal dan disampaikan dengan kewiraan, sehingga di Afrika Selatan banyak gerakan jihad yang bertujuan

\footnotetext{
${ }^{2}$ Perkuliahan dilakukan pada 20 Maret 2012.

${ }^{3}$ James Turner Johnson dalam The Holy War Idea in Western and Islamic Tradition mengemukakan bahwa Imperium Turki Usmaniyah dikenal sebagai imperium ghaza. Dinasti ini sangat bersungguh-sungguh dalam menjalankan kewajiban melindungi dan memperluas kekuasaan Islam, dan bahkan berusaha untuk membenarkan tuntutan mereka untuk menguasai seluruh dunia Islam. Puncak ghaza adalah ditaklukkannya Konstantinopel, ibukota imperium Byzantium, oleh Sultan Mehmed II atau Sultan Muhammad al-Fatih (memerintah tahun 1451-1484) pada tahun 1453 M. Daerah kekuasaan Imperium Turki Usmaniyah meliputi Armenia, Irak, Syiria, Hijaz, dan Yaman di Asia Kecil, lalu Mesir, Libya, Tunis dan Aljazair di Afrika, serta Bulgaria, Yunani, Yugoslavia, Albania, Hungaria dan Rumania di Eropa. Lihat James Turner Johnson, The Holy War Idea in Western and Islamic Tradition (terj) (Yogyakarta: Qalam, 1997), h. 239.
}

memurnikan Islam. ${ }^{4}$ Kelima adalah Indo-Pakistan Islamic cultural sphere yang berciri khas strong mystical tradition karena banyak dipengaruhi tradisi Hindu. Keenam adalah Chino Islamic cultural sphere yang sangat menghormati leluhur. Ketujuh adalah Western Islamic cultural sphere, di mana Islam masih mengalami keterancaman sehingga Islam menjadi semacam politic of identity, dan kedelapan adalah Nusantara Islamic cultural sphere, ${ }^{5}$ yang berciri khas

4 Beberapa gerakan Islam di Afrika yang bertujuan memurnikan Islam antara lain adalah gerakan yang dipimpin Usman dan Fadio (1754-1817 M) di Nigeria Utara yang memimpin gerakan jihad melawan penguasa Muslim dan pendukungnya yang dipandangnya korup dan menjalankan ajaran Islam yang bercampur baur dengan tradisi lokal. Demikian juga gerakan Grand Sanusi di Libya (1787-1859 M) dan gerakan Al-Mahdi di Sudan (1849-1885 M). Ciri gerakan revivalis Afrika ini adalah kepemimpinannya, antara lain ordo sufi yang berorientasikan politik, militan, dan reformis. Libya dan Sudan merupakan contoh tegas dari ordo sufi yang memimpin gerakan revivalis berbentuk jihad. Lihat John. L. Esposito, Islam and Politics (New York: Syracuse University, 1998), h. 40.

${ }^{5}$ Secara morfologi, kata majemuk ini berasal dari bahasa Jawa kuno, yaitu nusa (pulau) dan antara (lain/seberang). Istilah Nusantara dipakai untuk menggambarkan wilayah kepulauan yang membentang dari Sumatera hingga Papua. Sejarawan Indonesia mempercayai bahwa kata ini telah digunakan oleh Kertanegara, Raja Singasari terakhir pada tahun $1275 \mathrm{M}$, lalu kembali dicetuskan oleh Gajahmada pada tahun 1336 M. Kitab Negarakertagama mencantumkan wilayah Nusantara pada masa sekarang mencakup Sumatera, Kalimantan, Nusa Tenggara, Sulawesi dan pulau-pulau sekitarnya, Maluku, Papua Barat, dan ditambah Malaysia, Singapura, Brunei, dan Filipina bagian selatan. Pada awal abad ke-20, Ki Hajar Dewantoro kembali menghidupkan kembali istilah ini sebagai alternatif nama bagi negara pelanjut nama Hindia -Belanda, sebelum akhirnya tercetus nama Indonesia (berarti Kepulauan Hindia). Lihat "Pengertian 
Islam yang akomodatif, toleran, rilex, dan flowering. ${ }^{6}$

Lahirnya wajah Islam Nusantara yang akomodatif, rilex dan flowering bisa ditelusuri dari sejarah interaksi Islam-yang secara faktual turun di Tanah Hijaz, sebuah wilayah yang letaknya ribuan kilometer dari Nusantara dengan penduduk Nusantara yang telah ratusan tahun memeluk keyakinan animisme, dinamisme, kemudian Hindu dan Budha sebagai kepercayaan yang telah established sebelum datangnya Islam. Berbeda dengan ajaran Kristen yang dibawa seiring dengan masuknya era kolonialisme dan imperialisme Barat $^{7} \mathrm{di}$

Nusantara", sumber: http://id.facebook.Dunia Pengetahuan. Diakses 8/9/2014.

${ }^{6}$ Lihat juga Azyumardi Azra, Renaisans Islam Asia Tenggara; Sejarah Wacana dan Kekuasaan (Bandung: Remaja Rosdakarya, 1999), h. xv.

7 Kedatangan kolonialisme dan imperialisme Barat di Nusantara pada abad ke-16 disertai dengan missi $3 \mathrm{G}$, yaitu gold, glory and gospel. Di samping untuk mencari sumbersumber kekayaan (gold) berupa rempahrempah, emas, dan sebagainya, kerajaankerajaan Eropa juga berkeinginan untuk memperluas imperiumnya dengan mendirikan koloni dan menjajah wilayah-wilayah baru demi memperoleh kejayaan (glory). Selain itu, dalam missi penjelajahan ini,diikutsertakan para missionaries yang menjalankan missi zending untuk menyebarkan ajaran-ajaran Kristus (gospel) di daerah yang menjadi jajahannya. Menyatunya ketiga motif ini, yaitu motif ekonomi, politik dan agama dalam missi kolonialisme dan imperialisme terlihat dalam ucapan Alfonso d'Albuquerque, Panglima perang Kerajaan Kristen Portugis yang pada tahun 1511 melakukan agresi militer terhadap Kerajaan Islam Malaka yang saat itu diperintah Sultan Mahmud Syah II (1488$1511 \mathrm{M})$. Setelah membakar semua kapal orang Arab dan Cambay di Pelabuhan Malaka dan menyelamatkan kapal milik orang China dan non-Muslim, Alfonso berujar, “...jasa yang akan kita berikan kepada Tuhan kita dengan mengusir orang Moor (Islam-Arab) keluar dari negeri ini adalah memadamkan
Nusantara-yang karena itu segera menimbulkan perasaan permusuhan di tengah warga pribumi ${ }^{8}$ - Islam diperkenalkan di Nusantara antara lain dengan menggunakan jalur perdagangan, sebuah media yang sangat melekat dengan tradisi masyarakat Nusantara. Aktivitas perdagangan meniscayakan adanya interaksi sosial yang mutual antara penjual dan pembeli, kesederajatan, dan simbiosis mutualisme antara keduanya, serta jauh dari kesan permusuhan ataupun perasaan superioritas-inferioritas.

Selain melalui jalur perdagangan, media budaya menjadi salah satu sarana penyebaran Islam yang sangat efektif bagi masyarakat Nusantara, khususnya masyarakat Jawa. Para pendakwah Islam antara lain para Wali Songo, menggunakan media seni, baik seni wayang 9 , gamelan, sastra, dan

api dari agama Mohammet, sehingga api itu tidak akan pernah lagi menyebar sesudah itu. Saya yakin benar, jika kita rampas perdagangan Malaka ini dari mereka, Kairo dan Mekkah akan hancur...". Lihat Mualimbunsu Syam Muhammad, Motivasi Perang Sabil di Nusantara (Jakarta: Media Madania, 2013), h. 96.

8 Sartono Kartodirdjo mencatat dua bentuk rekasi terhadap penetrasi Barat (Belanda) di Indonesia. Sikap radikal menolak diperlihatkan oleh para pemimpin agama, sedangkan sikap menerima dan adaptif diperlihatkan kaum adat, seperti pangrehpraja di Jawa, kaum adat di Sumatera Barat, dan oeloebalang di Aceh. Perbedaan respons ini dipengaruhi oleh kedudukan dan sikap religius mereka masing-masing. Lihat Sartono Kartodirdjo, Pengantar Sejarah Indonesia Baru 1500-1900 (Jakarta: Gramedia Pustaka Utama, 1999), h. 374.

${ }^{9}$ Sunan Kalijaga misalnya, memasukan unsurunsur ajaran Islam ke dalam pertunjukan seni wayang. Pengenalan jamus kalimosodo (dua kalimat syahadat), juga penggambaran empat tokoh punakawan yang digambarkan arif dan bijaksana, yaitu Semar, Gareng, Petruk dan Bagong, adalah personifikasi dari ucapan Ali bin Thalib, "itsmar khairan, fatruk ma bagha" (kerjakan yang baik dan tinggalkan 
sebagainya, sebagai sarana untuk mengintrodusir Islam, sehingga mudah menarik minat dan hasrat masyarakat Jawa yang memang sangat familiar dengan seni tersebut terhadap agama baru ini. Mereka menghindarkan caracara radikal dalam menyebarkan Islam, dan sebaliknya, mengambil cara-cara persuasif dan damai (penetration pacifique) dengan tetap membiarkan dan mengakomodir tradisi yang telah melekat sebelumnya di tengah masyarakat. Doktrin al-muhâfazatu 'alâ al-qadîmi al-șalih wa al-akhdzu bi aljadîd al-aṣlah (memelihara hal-hal lama (tradisi) yang baik dan mengambil halhal baru yang lebih baik) menjadi doktrin yang sampai sekarang dipegang erat oleh kaum Islam tradisionalis dalam memelihara tradisi-tradisi lama.

Kokohnya Islam Nusantara yang moderat dan akomodatif tidak hanya disebabkan cara-cara persuasif yang digunakan para pendakwah dalam menyebarkan risalah Islam, akan tetapi juga ditopang oleh legitimasi penguasa politik (kerajaan Islam). Dalam tradisi sejarah Nusantara, lahirnya simbiosis mutualisme antara pemuka agama dan penguasa kerajaan telah berlangsung lama sejak kerajaan Hindu dan Budha.

Sejarawan LIPI, Asvi Warman Adam, menjelaskan bahwa bentuk simbiosis ini adalah berupa pemberian legitimasi dari pendeta kepada raja bahwa raja adalah titisan dewa, sementara pendeta mendapatkan emas dari sang raja. Pada akhirnya, Hindu dan Budha bahkan menjadi agama resmi negara. Dalam naskah kuno Ramayana Kakawin misalnya, ditegaskan adanya rajadharma, yaitu tugas dan kewajiban seorang raja. Salah

yang jelek). Dengan metode penyebaran persuasif seperti ini, islamisasi budaya Nusantara berjalan dengan sangat damai dan dapat diterima dengan tanpa menimbulkan resistensi penduduk lokal. satu ajaran rajadharma adalah asthabrata, yaitu perilaku berjumlah delapan. Maksudnya adalah seorang raja haruslah memiliki perpaduan jiwa dari delapan dewa, yaitu Dewa Indra, Yama, Surya, Soma, Wayu, Kuwera, Waruna dan Agni. ${ }^{10}$ Warisan kerajaan Hindu dan Budha di Indonesia dapat dilihat dari bangunan-bangunan candi yang tersebar di beberapa wilayah di Jawa dan Sumatera, yang mencerminkan perhatian penguasa terhadap kehidupan beragama saat itu. ${ }^{11}$

Islamisasi di ranah politik berjalan demikian cair, tanpa ada pergolakan sama sekali. Ulama memerlukan perlindungan demi memperlancar dakwahnya, sedangkan penguasa (raja) membutuhkan legitimasi dari ulama sebagai 'wakil Tuhan di bumi' agar lebih legitimate di depan rakyat. Oleh karena itu, umumnya raja-raja atau ataupun keluarga raja kerajaan Islam segera berganti nama menjadi nama Islam atau menyematkan gelar keagamaan di belakang namanya.

Penguasa Kerajaan Pasai, Merah Silau segera berganti nama menjadi Sultan Malik al-Shalih. Kemudian Raja Mataram yang bernama Raden Mas Jatmiko (memerintah 1613-1645 M) atau nama lainnya adalah Raden Rangsang, juga memiliki gelar Sultan Agung Adi Prabu Hanyokrokusumo, sebuah gelar pemberian Syarif Mekkah setelah utusannya pada tahun $1641 \mathrm{M}$ menghadap ke Syarif Mekkah. ${ }^{12}$ Sedangkan Pangeran Diponegoro, yang masih berasal dari keluarga kerajaan Mataram bergelar Sultan Ngabdulkamid Herucakra Kabirulmukminina Kalifatul

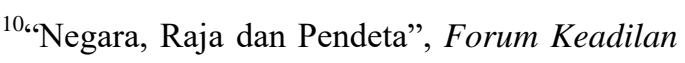
Edisi 31 Desember 2000.

${ }^{11}$ Bernard H.M. Viekke, Nusantara; A History of Indonesia (terj), (Jakarta: Gramedia, 2008), h. 32-35.

12 Azyumardi Azra, Renaisans Islam Asia Tenggara, $h .78$.
} 
Rasulullah Hamengkubuwana Senapati Ing Ngalaga Sabilullah Ing Tanah Jawa. ${ }^{13}$ Sebutan raja pun berganti dengan istilah sultan. Gelar keagamaan ini bertujuan untuk semakin mengukuhkan kedudukan mereka tidak hanya sebagai pemimpin sosial dan penguasa politik, tetapi juga sebagai pemimpin spiritual. Kemanunggalan sejati antara raja, ulama dan rakyat juga tampak dalam tata letak yang menyatu (berdekatan) antara keraton sebagai simbol kekuasaan kerajaan, masjid sebagai tempat ibadah yang merepresentasikan kekuasaan ulama, dan alun-alun sebagai representasi tempat berkumpulnya rakyat. Gambaran tiga komponen ini hampir selalu terlihat di setiap pusat kerajaan di Nusantara, khususnya di Jawa.

Beberapa faktor inilah yang menyebabkan Islam di Nusantara memiliki watak dan karakteristik yang lebih ramah, toleran, dan akomodatif. Hal ini tentu saja berbeda dengan wajah Islam di Timur Tengah, Asia Selatan dan Afrika yang mengalami ekspansi Islam antara lain melalui jalur

\footnotetext{
${ }^{13}$ Peter Carey, The Power of Prophecy; Prince Dipanegara and The End of an Old Order in Java, 1785-1855 (Leiden: KITLV Press, 2007), h. 72. Pangeran Mangkubumi yang kemudian bergelar Sultan Hamengkubuwono I, pendiri Keraton Ngayogyakarta Hadiningrat, menambahkan gelar dibelakang namanya, yaitu Senopati Ing Ngalogo Abdurrahman Sayidin Panata Gama Kalifatullah. Senopati Ing Ngalaga artinya panglima perang, Abdurrahman adalah manusia yang mendapatkan kasih sayang Nya, panatagama menggambarkan manusia yang menjadi pengelola agama yang mempunyai orientasi surgawi, sedangkan kalifatullah adalah cerminan penguasa yang mendapat nur Illahi, yang memerintah sebagai waliyullah di muka bumi. Lihat GBPH $\mathrm{H}$. Joyokusumo, Spiritual Islam dan Perspektif Budaya Jawa, dalam Aswab Mahasin dkk (ed), Ruh Islam dalam Budaya Bangsa (Jakarta: Yayasan Festifal Istiqlal, 1996), h. 227.
}

pembebasan (futuh) dan terkadang melibatkan kekuatan militer. Meskipun tidak selalu terjadi pemaksaan penduduk untuk memeluk Islam, akan tetapi wilayah-wilayah ini kemudian lebih intens mengalami proses Arabisasi. Sedangkan di wilayah Asia Tenggara (Nusantara), hampir tidak pernah terjadi futuh, sehingga sering disebut sebagai the least Arabicized, paling kurang mengalami Arabisasi. ${ }^{14}$

Karena akomodatifnya Islam Nusantara terhadap tradisi lokal, banyak pengamat yang menilai Islam di Nusantara sebagai Islam sinkretis, Islam periferal, atau sebutan lainnya yang menggambarkan betapa Islam Nusantara bukanlah Islam sesungguhnya dibandingkan dengan Islam seperti di negara asalnya, Timur Tengah. Islam di Nusantara lebih banyak didominasi tradisi dan sistem kepercayaan lokal yang terkadang tidak sesuai dengan ajaran Islam sesungguhnya, sehingga mengarah pada praktik-praktik takhayul, bid'ah dan khurafat.

Terhadap realita wajah Islam Nusantara yang disebut sebagai Islam periferal, Islam sinkretis, Islam adat, atau sebutan lainnya yang sejenis, beberapa ormas Islam berbeda dalam mensikapinya. Muhammadiyah, Persis, Al-Irsyad, dan sejenisnya, tampil dengan gerakan purifikasi yang menginginkan pemurnian ajaran Islam dari segala praktek anti tauhid. ${ }^{15}$ Hanya

\footnotetext{
14 Azyumardi Azra, Renaisans Islam Asia Tenggara, h. xvi.

15 Sejarawan Deliar Noer mengelompokkan organisasi Islam keagamaan di Indonesia ke dalam dua kategori besar, yaitu pertama gerakan modernis yang direpresentasikan antara lain oleh Muhammadiyah, Al-Irsyad, dan Persis. Kedua, kelompok Islam tradisionalis, yang direpresentasikan antara lain oleh NU, Perti (Persatuan Tarbiyah Indonesia), dan sebagainya. Lihat Deliar
} 
saja, mereka tetap saja lebih memilih untuk mengedepankan pendekatan persuasif dalam dakwahnya dibandingkan dengan cara-cara radikal. ${ }^{16}$ Sehingga banyak masyarakat mau menerima dakwah mereka dan bahkan gerakan ini tetap bisa eksis sejak berdirinya di awal abad ke-20 hingga sekarang ini. Terhadap tradisi lokal, mereka tetap memberikan ruang dan menerimanya sebagai bagian dari praktik keberagamaan sepanjang tidak ada nash yang jelas dan tegas melarang tradisi tersebut. Akan tetapi jika terdapat nash yang jelas melarangnya, mereka akan meninggalkannya, terlebih yang berkaitan dengan praktik ibadah mahdhah. Inilah yang oleh Muhammadiyah disebut sebagai Dakwah Kultural, yaitu menjadikan budaya sebagai sarana dakwah, seperti pribumisasi Islam yang pernah dilakukan Walisongo.

Berbeda dengan Muhammadiyah, organisasi tradisionalis Nahdlatul Ulama (NU) sejak berdirinya telah mendeklarasikan dirinya sebagai organisasi pelestari tradisi. Doktrin almuhâfazatu 'alâ al-qadîmi al-ṣâlih wa al-akhdzu bi al-jadîd al-aṣlah

Noer, Gerakan Modern Islam di Indonesia (Jakarta: LP3ES, 1996).

${ }^{16}$ Gerakan Paderi (1803-1834 M) di Sumatera Barat sempat menerapkan cara-cara radikal dalam usaha purifikasi agama. Gerakan yang dipimpin trio haji, yaitu Haji Piobang, Haji Sumanik dan Haji Miskin banyak dipengaruhi ajaran Wahhabi sepulang mereka dari Tanah Hijaz pada tahun 1803. Namun pada akhirnya terjadi rekonsiliasi antara ulama Paderi dengan tokoh kaum adat yang menghasilkan sebuah kesepakatan, adat basandi syara, syara basandi kitabullah, yang menggambarkan keselarasan antara tradisi dan syariat agama yang berlaku untuk masyarakat Minangkabau. Uraian detail tentang Gerakan Paderi lihat M.D. Mansoer, Sedjarah Minangkabau (Jakarta: Bhratara:, 1970), Murodi, Melacak Asal-usul Gerakan Paderi di Sumatera Barat (Jakarta: Logos, 1999). (memelihara tradisi yang baik dan mengambil hal-hal baru yang lebih baik) telah mendarah daging di benak setiap warga Nahdliyin sebagai acuan mereka dalam meyakini diperbolehkannya tradisi sebagai bagian dari praktik-praktik ibadah dan syariah. Mereka memiliki argumentasi teologis dalam memegang teguh keyakinan ini. Menurut mereka, pada masa Nabi Muhammad SAW, Islam hadir dengan suasana dialogis dengan budaya lokal masyarakat Arab, sehingga ia tidak berdiri sendiri.

Beberapa praktik ritual keagamaan seperti tawâf, șalat istisqâa, dan sebagainya adalah tradisi Arab yang sudah ada sebelum Islam dibawa Nabi Muhammad. Oleh karena itu, menurut mereka, Islam sesungguhnya dibesarkan oleh lokalitas. Dengan kata lain, Islam dan lokalitas harus dikawinkan. ${ }^{17}$

Dalam analisis Nurcholish Madjid, hasil peradaban maupun pemikiran manusia akan lebih tangguh jika ia memiliki akar pada tradisi, mengandung orisinalitas (al-aṣlah), dan bersifat relevan (mu'șarah, up to date). ${ }^{18}$ Akulturasi timbal balik antara Islam dan budaya lokal-ilmu Ushul alFiqh disebut juga 'urf-sangat dimungkinkan dan diakui dalam suatu

\footnotetext{
${ }^{17}$ Lihat Post Tradisionalisme Islam; Wacana Intelektualisme dalam Komunitas $N U$, (Jakarta: Dirjen Pendidikan Islam Depag RI, 2007), h. 300. Kalangan Nahdliyin menyebut gagasan pembumian nilai-nilai Islam ke dalam tradisi lokal Indonesia sebagai Islam Pribumi. Gagasan ini bertujuan menghindari klain otensitas, bahwa Islam yang otentik adalah Islam Timur Tengah, sehingga tercipta pola-pola keberagamaan yang sesuai dengan konteks lokal. Islam tidak lagi dipandang secara tunggal, melainkan beraneka ragam. Islam Indonesia, dengan segala macam pernak-perniknya, juga adalah Islam.

${ }^{18}$ Orasi ilmiah Nurcholish Madjid dalam acara pembukaan Muktamar pemikiran Islam NU di Ponpes Salafiyah Syafi‘iyah Sukorejo, Situbondo, 5 Oktober 2003.
} 
kaidah ushul fiqh, bahwa al-'Adah muhakkamah (adat dan kebiasaan 'budaya lokal' adalah sumber hukumdalam Islam).

Cak Nur menambahkan bahwa budaya lokal yang bisa dijadikan sumber hukum adalah yang tidak bertentangan dengan prinsip-prinsip Islam dan tidak melanggar ajaran tauhid, seperti tahayul, mitologi, feodalisme, tata sosial tanpa hukum (laotik), ketidakperdulian terhadap rakyat kecil, pengingkaran hak asasi, perlawanan terhadap prinsip persamaan umat manusia, dan sebagainya. Karakteristik jahiliyah ini harus diganti dengan prinsip-prinsip ajaran tauhid, seperti tertib hukum, rasionalitas, penghargaan terhadap sesama manusia, keadilan sosial, persamaan antarumat manusia (al-musâwah, egalitarianisme), dan sebagainya. ${ }^{19}$

Untuk bisa membedakan mana budaya lokal yang baik dan mana yang tidak baik, tentu saja harus dikembangkan sikap kritis dari umat Islam demi terjadinya sebuah transformasi sosial yang baik. Untuk itu, Cak Nur membedakan antara "tradisi" dan "tradisionalitas".

Menurutnya, dalam suatu tradisi belum tentu semuanya tidak baik. Oleh karena itu, perlu sikap kritis dan ketelitian untuk memilah mana yang baik dan perlu dipertahankan, dan mana yang tidak. Sementara itu, tradisionalitas merupakan sikap tertutup akibat pemutlakan terhadap tradisi secara keseluruhan, tanpa sikap kritis mana yang baik dan mana yang buruk, dan karena itu, tradisionalitas pasti tidak baik. ${ }^{20}$ Jika ini dipahami, niscaya tidak

19 Nurcholish Madjid, Islam Doktrin dan Peradaban (Jakarta: Paramadina, 2000), IV, h. 550 .

20 Nurcholish Madjid, Islam Doktrin dan Peradaban, h. 553. akan muncul dikotomi antara tradisi dan modernitas.

Selanjutnya, Cak Nur menegaskan bahwa memang kedatangan Islam akan membawa sebuah perubahan dan perombakan masyarakat (transformasi sosial) menuju kea arah yang lebih baik. Akan tetapi, di saat yang sama, hadirnya Islam tidak harus bersifat disruptive atau memotong suatu masyarakat dari masa lampaunya semata, namun bisa ikut melestarikan dan mempertahankan sesuatu yang baik dari masa lampau tersebut. ${ }^{21}$ Inilah yang telah dilakukan Walisongo dengan konsep Pribumisasi Islam, yang banyak melahirkan kearifan dan budaya lokal, seperti yang terlihat dalam tradisi sekatenan di pusat-pusat kekuasaan Islam seperti di Yogyakarta, Solo, Demak, Cirebon, dan sebagainya, juga bangunan-bangunan masjid yang masih mempertahankan bangunan aslinya.

\section{B. Pembahasan}

\section{Beberapa Warisan Islam Nusantara}

Keberhasilan perkawinan antara
tradisi lokal dan Islam yang
menghasilkan berbagai local wisdom
(kearifan lokal) bisa disaksikan dalam
banyak dimensi kehidupan masyarakat
Muslim Indonesia. Berbagai
peradaban $^{22}$ Nusantara hasil akulturasi

${ }^{21}$ Nurcholish Madjid, Islam Doktrin dan Peradaban, h. 551

22 Budayawan Kuntjaraningrat menjelaskan bahwa wujud budaya ada tiga, pertama adalah wujud benda. Peradaban adalah salah satu wujud atau bentuk budaya yang berupa benda, di dalamnya termasuk sistem teknologi, seni bangunan, seni rupa, sistem kenegaraan, dan sebagainya. Wujud budaya yang kedua menurut Kuntjaraningrat adalah berupa ide-ide, norma, gagasan, peraturan, hukum, dan sebagainya, dan wujud budaya ketiga berupa tingkah laku. Dengan kata lain, peradaban adalah bagian dari budaya, tapi tidak sebaliknya. 
dengan Islam antara lain terlihat dalam berbagai bangunan masjid yang mencerminkan perkawinan budaya yang sangat serasi.

Di Kudus, Masjid Agung Kudus menjadi saksi bisu betapa antara Islam dan budaya Hindu bisa saling berasimiliasi tanpa saling mengalahkan satu sama lain. Menara masjid dibiarkan seperti apa adanya berbentuk candi. Begitu juga Masjid Agung Demak yang dibangun oleh Walisongo, dibangun dengan memadukan unsur lokalitas Jawa dengan ruh ajaran Islam. Arsitekturnya masih bergaya Hindu, sedangkan atapnya yang berundak tiga dimaksudkan untuk mencerminkan tiga bangunan suci ajaran Islam yaitu iman, Islam dan ihsan. ${ }^{23}$ Bentuk bangunan beratap susun terdapat pada relief-relief candi di Jawa Timur, seperti candicandi di Surawana, Jawa dan jago. Pijper bahkan berasumsi bahwa bentuk atap susunan masjid merupakan kelanjutan tradisi (survival) dari meru. ${ }^{24}$

Tidak hanya welcome dengan nilai-nilai keislaman yang muncul dari Timur Tengah, lokalitas Nusantara juga bisa berbaur dengan tradisi budaya bangsa lain. Bangunan Masjid Cheng Ho di beberapa daerah ${ }^{25}$ mencerminkan betapa Muslim Nusantara juga sangat akomodatif terhadap budaya luar (baca: China). Begitu juga Masjid Lao Tze yang dibangun komunitas China Muslim di Jakarta, yang mengadopsi

\footnotetext{
${ }^{23}$ Uraian detail tentang berbagai masjid yeng bersejarah lihat Abdul Baqir Zein, MasjidMasjid bersejarah di Indonesia (Jakarta: Gema Insani Press, 1999).

24 Hasan Muarif Ambary, Menemukan Peradaban Arkeologi dan Islam di Indonesia ((Jakarta:Pulit Arkenas, 1998), h. 259.

${ }^{25}$ Masjid Cheng Ho ada di Semarang, Surabaya dan Palembang. Masjid Cheng Ho di Palembang disebut juga Masjid Cheng Ho Sriwijaya, didesain dengan perpaduan akulturasi antara Tiongkok, Timur Tengah dan lokal Palembang.
}

tradisi bangunan lokal China dipadupadankan dengan tradisi Islam.
Selain
bangunan-bangunan

masjid, warisan Islam Nusantara lainnya adalah lahirnya mushaf AlQur'an Nusantara yang berbeda karakteristiknya dengan mushaf AlQur'an Timur Tengah. Fadhal AR Bafadhal dan Rosihan Anwar mencatat bahwa aktifitas penulisan mushaf telah berlangsung sejak abad ke-13 pada masa Kerajaam Samudera pasai. Selanjutnya, sejarah mencatat bahwa geliat penulisan mushaf Al-Qur'an Nusantara pada abad 16 hingga abad 20 banyak disponsori oleh kerajaan, pesantren, dan elit sosial. Mushaf AlQur'an Nusantara ini memiliki karakteristik yang unik, antara lain terdapat catatan tambahan seperti tajwid, dan kaligrafi yang digunakan sederhana.

Ada yang menggunakan khat Naskhi untuk ayat, dan khat Tsuluts untuk penulisan juz. Ada pula yang menggunakan kaligrafi floral atau gaya tulisan lokal, sedangkan mushaf Timur Tengah menggunakan gaya hias geometris. Mushaf Al-Qur'an Nusantara kuno ini banyak ditemukan di bekas pusat kerajaan lama dan di antaranya masih tersimpan di beberapa pesantren, seperti Pesantren Telagasari, Ponorogo, Buntet Cirebon, dan sebagainya. $^{26}$

Warisan Islam Nusantara lainnya yang tak ternilai harganya tentulah munculnya banyak ulama Nusantara beserta maha karyanya yang hingga kini terus menjadi mata air pengetahuan dan

\footnotetext{
${ }^{26}$ Fadhal AR Bafadhal dan Rosihan Anwar, Mushaf-Mushaf Kuno di Nusantara, disarikan dari "Pasang Surut Penulisan Mushaf Nusantara", Republika, 7 September 2014. Museum Baitul Qur'an di Taman Mini Indonesia Indah (TMII) menyimpan ragam mushaf Al-Qur'an dari berbagai daerah di Nusantara dengan berbagai karakteristik dan ukuran.
} 
penelitian para intelektual Indonesia maupun dunia. ${ }^{27}$ Munculnya maha karya bernilai tinggi di berbagai bidang keilmuan, baik tafsir, hadith, tasawuf, fikih, tauhid, sastra Islam, tarikh (sejarah) dan sebagainya ini bisa ditelusuri dari sejarah awal tradisi intelektual Islam Nusantara. Hal ini tidak bisa dilepaskan dari terjalinnya jaringan antara ulama MelayuNusantara dengan ulama-ulama Tanah Haramayn sejak abad ke-17. ${ }^{28}$ Sebagai pusat ibadah dan pusat studi Islam ketika itu, para ulama Nusantara berziarah ke Tanah Haramayn tidak sekedar menunaikan rukun Islam ke lima, melainkan juga untuk menuntut ilmu. Di antara mereka ada yang kemudian pulang dan berkarir di tanah air dan mengembangkan ajaran dan ilmu-ilmu keislaman di daerah masingmasing, dan sebagian kecil lagi mengembangkan karir keilmuannya di Tanah Haramayn.

\footnotetext{
${ }^{27}$ Berbeda dengan karya ilmiah para ulama di luar Nusantara yang ditulis dengan bahasa dan tulisan yang homogen, yaitu bahasa dan huruf Arab, karakteristik istimewa karya ilmiah ulama Nusantara ditulis cukup heterogen, yaitu dengan berbagai bahasa lokal, seperti bahasa Melayu, Jawa, Aceh, Minangkabau, Sunda, Madura, Bugis, Sasak, dan sebagainya, serta ditulis dengan aksara lokal pula, seperti aksara Jawa, Pegon, Serang, Rejang, Kaganga, Palawa, dan sebagainya. Lihat Oman Fathurahman, "Tradisi Penulisan Kitab Hadis di Dunia Melayu-Nusantara; Tinjauan Khusus atas Hidayat al-Habib Karangan Nuruddin alRaniri”, makalah disampaikan dalam perkuliahan di Sekolah Pascasarjana mata kuliah History of Southeast Asian Islam; Social Intellectual, Selasa, 3 April 2012

28 Uraian detail tentang jaringan ulama Nusanatara lihat Azyumardi Azra, Jaringan Ulama Timur Tengah dan Kepulauan Nusantara Abad XVII-XVIII (Bandung: Mizan, 2004).
}

Beberapa nama ulama yang pernah melakukan studi di Tanah Haramayn yang kemudian dikenal dengan sebutan jamâ'at al-Jâwiyîn (komunitas Jawi) $^{29}$ di Mekah antara lain Nuruddin al-Raniry (w. 1658 M), Abdurrauf bin Ali al-Jawi al-Fansuri (1615-1693 M), Yusuf al-Maqassari (1629-1699 M), Abdussamad alPalimbani, Arsyad al-Banjari (17101812 M), Dawud al-Fattani (w. 1847 M), Nawawi al-Bantani (1813-1879 M), Mahfudz al-Tarmasy (w.1919 M), Ahmad Rifa'i Kalisasak (1786-1870 M), Ahmad Khatib Sambas (1803-1875 M), Muhammad Saleh Darat alSamarani (w. 1903 M), Ahmad Khatib al-Minangkabawi (1860-1916 M), ${ }^{30}$ K.H. Ahmad Dahlan (1868-1923 M), K.H. Hasyim Asy'ari (1871-1947 M), dan masih banya lagi. Di tangan komunitas Jawi inilah, seperti yang diungkapkan Snouck Hurgronye, Mekkah memegang peranan penting sebagai jantung kehidupan keagamaan di Nusantara. ${ }^{31}$

Setelah berguru di Tanah Haramayn, beberapa ulama di atas kemudian mengembangkan keilmuannya di tanah air. Nuruddin alRaniry dan Abdurrauf al-Sinkili, seperti yang kita tahu, selain mengembangkan keilmuannya di tanah air khususnya

\footnotetext{
${ }^{29}$ Istilah Jawi (Jawa) digunakan untuk merujuk pada para pelajar Muslim asal Asia Tenggara yang belajar di Tanah Haramayn (Mekkah), mencakup wilayah Indonesia, Malaysia, Patani di Thailand Selatan, Brunei, Filipina, kamboja dan Myanmar. Lihat Oman Fathurahman, "Jaringan dengan Timur Tengah dan Menguatnya Diskursus Islam Berorientasi Syariah", makalah disampaikan dalam perkuliahan di Sekolah Pascasarjana mata kuliah History of Southeast Asian Islam; Social Intellectual, Selasa, 17 April 2012.

${ }^{30}$ Oman Fathurahman, "Tradisi Penulisan Kitab Hadis di Dunia Melayu-Nusantara".

${ }^{31}$ Oman Fathurahman, "Jaringan dengan Timur Tengah dan Menguatnya Diskursus Islam Berorientasi Syariah".
} 
fikih, syariah, hadits dan tafsir, juga berkarir di dunia politik dengan menjadi mufti (Syaikh al-Islam) di Kerajaan Aceh Darussalam pada masa pemerintahan Sultan Iskandar Tsani (1637-1641M) (lihat buku 100 tokoh). Karya Nuruddin al-Raniry di bidang fikih, Șirât al-Mustaqîm merupakan kitab fikih ibadah pertama dalam Bahasa Melayu. Di bidang hadith, karya nya berjudul Hidâyât al-Habîb fî alTarghîb wa al-Tarhîb dianggap sebagai kitab hadith pertama dalam Bahasa Melayu. Kitab yang diperkirakan ditulis pada 6 Syawal 1045 H/14 Maret 1636 $M$ ini berisi 831 buah hadith dari berbagai sumber, seperti kitab Bukhârî, Muslim, Turmudhî, dan sebagainya. ${ }^{32}$

Pada masa karirnya menjadi Syaikh al-Islam, Nuruddin al-Raniry pernah berpolemik dengan Hamzah alFansuri dan Syamsuddin al-Sumatrani yang mengembangkan ajaran sufisme falsafi. Menurut al-Raniry, ajaran yang dikembangkan kedua organisasi ini berupa ajaran wihdatul wujud sebagai paham yang sesat dan membahayakan aqidah, dan karena itu harus diberangus. Lewat kekuasaan yang dimilikinya, ia melakukan aksi radikal dan revolusioner dengan membakar semua karya Hamzah al-Fansuri dan Syamsuddin al-Sumatrani di depan Masjid Baiturrahman, Aceh dan menghukum keduanya sebagai murtad. Dalam karyanya yang berjudul al-Fath al-Mubinn ala al-Mulhidîn (kemenangan terhadap golongan atheis), al-Raniry bahkan menduduh al-Fansuri sebagai ulama zindiq. ${ }^{33}$

\footnotetext{
${ }^{32}$ Oman Fathurahman, "Tradisi Penulisan Kitab Hadis di Dunia Melayu-Nusantara".

${ }^{33}$ Shalahuddin Hamid dan Iskandar Ahza, 100 Tokoh Islam paling Berpengaruh di Indonesia (Jakarta; Nusantara Lestari ceriapratama, 2004), 138. Lihat juga Azyumardi Azra, Jaringan Ulama, h. 169.
}

Sementara itu, Abdurrauf alSinkili yang kemudian melanjutkan karir Al-Raniry sebagai mufti pada masa kekuasaan Sultanah Tajul Alam (1641-1674) berhasil melakukan rekonsiliasi antara para penganut sufisme falsafi dengan para penganut sufisme akhlaqi. Beberapa karya yang ditorehkan Abdurrauf al-Sinkili antara lain kitab Mir'ât al-Țulâb yang merupakan kitab fikih muamalat pertama dalam Bahasa Melayu. Karya al-Sinkili yang lain antara lain kitab Tarjumân al-Mustafid, sebuah karya ilmiah bidang tafsir berbahasa Melayu pertama yang penyusunannya banyak diilhami Tafsir al-Jalâlayn karya alSuyûtî. ${ }^{34}$

Selain kedua ulama ini, beberapa ulama Nusantara yang telah mewariskan karyanya bagi Muslim Nusantara adalah Dawud bin Abdullah al-Fattani (w. $1847 \mathrm{M}$ ), yang menulis kitab di bidang hadith berjudul Farâ'id Fawâ'id al-Fikr fi al-Imâm al-Mahdi. Meskipun kitab ini merupakan karya terjemahan dari kitab Shaikh Mirghâni ibn Yûsuf dengan judul yang sama, namun kitab yang selesai ditulis pada tahun 1215 $\mathrm{H} / 1800 \mathrm{M}$ ini dianggap sebagai kitab hadith berbahasa Melayu pertama yang secara khusus membicarakan tentang Imam Mahdi. ${ }^{35}$

Sementara itu, beberapa ulama Nusantara pada akhirnya memutuskan untuk tidak kembali ke tanah air dan memilih berkarir di Tanah Haramayn. Syaikh Nawawi al-Bantani, Mahfudz alTarmasy, dan Ahmad Khatib alMinangkabawi adalah beberapa anggota komunitas ulama Jawi yang melakukan hal ini. Nawawi bin Umar binn Arabi atau yang lebih dikenal sebagai Nawawi al-Bantani merupakan ulama asal Desa

\footnotetext{
${ }^{34}$ Oman Fathurahman, "Tradisi Penulisan Kitab Hadis di Dunia Melayu-Nusantara".

${ }^{35}$ Oman Fathurahman, "Tradisi Penulisan Kitab Hadis di Dunia Melayu-Nusantara".
} 
Tanara, Tirtayasa, Kabupaten Serang, Banten.

Setelah berguru selama hampir 30 tahun dengan ulama-ulama besar di Mekkah, al-Bantani pun memulai karirnya sebagai salah satu pengajar di Masjidil Haram. Karena itulah ia dipanggil dengan sebutan Syaikh, guru besar. Murid-muridnya berasal dari berbagai negeri Islam. Di antara murid al-Bantani yang kemudian juga menjadi ulama besar di Nusantara antara lain adalah KH Kholil Bangkalan, KH Asy'ari Bawean Madura, KH Hasyim Asy'ari Jombang, KH Raden Asnawi dari Kudus, juga KH Dawud dari Perak, Malaysia. Banten menjadi sangat populer di mata para jamaah haji dan pelajar Islam seluruh dunia berkat kemasyhuran al-Bantani. Selama 69 tahun pengabdiannya dalam mengajarkan ilmu-ilmu Islam di Mekkah, ia telah menghasilkan berbagai macam mahakarya di berbagai bidang keilmuan, seperti ilmu tafsir, tauhid, fikih, akhlak, tarikh, bahasa Arab, dan sebagainya. Karena kepopulerannya inilah kitab al-Munjid mengabadikan nama Nawawi al-Bantani sebagai tokoh Indonesia yang tercantum di dalamnya sebelum nama Soekarno. Karyakaryanya di berbagai bidang seperti tafsir al-Munir, Bidayatul Hidayah, Lubab al-Bayan, Fath al-Majid, dan masih banyak lagi, hingga sekarang masih menjadi referensi utama di pesantren-pesantren, madrasah hingga perguruan tinggi di seluruh pelosok dunia Islam seperti Timur Tengah, Asia, maupun Indonesia. ${ }^{36}$

Sementara itu, Muhammad Mahfudz bin Abdullah bin Abdul Manan bin Abdullah bin Ahmad alTarmasi yang lahir di Termas, Pacitan, pada 12 Jumadil Awal 1285 H/31

\footnotetext{
${ }^{36}$ Shalahuddin Hamid dan Iskandar Ahza, 100 Tokoh Islam paling Berpengaruh di Indonesia.
}

Agustus $1868 \mathrm{M}$ dan wafat di Mekkah pada 1 Rajab 1338 H/20 Mei 1919 M, dikenal sebagai ulama Nusantara paling terkemuka di bidang hadith.

Sedangkan Ahmad Khatib alMinangkabawi yang lahir di Bukittingi, Sumatera Barat pada tahun 1860 merupakan ulama Nusantara yang berhasil mencapai puncak karir intelektualnya sebagai Imam Besar Masjidil Haram. Di antara muridmuridnya antara lain adalah pendiri organisasi Muhammadiyah yaitu KH Ahmad Dahlan, pendiri NU KH Hasyim Asy'ari, Syaikh Muhammad Nur (Mufti Kerajaan Langkat), Syaikh Hasan Maksum (Mufti Kerajaan Deli), Syaikh Muhammad Saleh (Mufti Kerajaan Selangor), Syaikh Muhammad Jamil Jambek, Syaikh Ibrahim Musa, Abdul Malik Karim Amrullah, Syaikh Sulaiman rasul, dan sebagainya. ${ }^{38}$

Meski bermukim di Mekkah, namun Ahmad Khatib al-Minangkabawi tetap memberikan perhatian terhadap persoalan-persoalan yang dihadapi bangsa Indonesia. Di antara tulisannya adalah Al-Manhaj al-Marsyu yang berisi respons dan kritik terhadap masalah pembagian warisan serta sistem keturunan matrilineal. Tulisannya ini banyak mendapat penolakan dari pemangku adat Minagkabau. Selain itu, tulisannya yang berjudul Izhar Zagli al-Kâzibîn fî Tasyabbuhihim bi al-Sâdiqîn merupakan kritik terhadap Tariqat Naqsabandiyah yang menurutnya tidak memiliki dasar dalam syariat Islam. Bukunya yang berjudul Dau al-Siraj yang ditulis tahun $1312 \mathrm{H}$ membahas peristiwa Isra Mi'raj dan sikap politiknya yang tidak menyukai

\footnotetext{
${ }^{37}$ Oman Fathurahman, "Tradisi Penulisan Kitab Hadis di Dunia Melayu-Nusantara".

${ }^{38}$ Shalahuddin Hamid dan Iskandar Ahza, 100 Tokoh Islam paling Berpengaruh di Indonesia, h, 111.
} 
penjajah Belanda di Indonesia, tanah airnya. ${ }^{39}$ Begitu juga karya-karyanya yang lain di bidang ushul fiqih, ilmu hisab, fiqih, dan sebagainya menunjukkan kapabilitasnya sebagai ulama yang produktif.

Dua murid Ahmad Khatib alMinangkabawi, yaitu Ahmad Dahlan dan Hasyim Asy'ari sepulangnya dari Tanah Haramayn pada akhirnya tampil sebagai ulama pembaharu di tanah air. Meski pernah mendalami dari satu orang guru, keduanya memiliki perbedaan pandangan dalam hal-hal keagamaan. Ahmad Dahlan pada akhirnya mendirikan Muhammadiyah ${ }^{40}$ sebagai gerakan modernis yang salah satu tujuannya adalah melakukan purifikasi terhadap ajaran-ajaran Islam. Sedangkan Hasyim Asy'ari adalah salah satu pendiri Nahdlatul Ulama yang salah satu motivasi pendiriannya adalah untuk melestarikan nilai-nilai tradisi. ${ }^{41}$ Kedua ormas keagamaan ini hingga kini tetap eksis dan tumbuh sebagai ormas terbesar di Indonesia.

\footnotetext{
${ }^{39}$ Shalahuddin Hamid dan Iskandar Ahza, 100 Tokoh Islam paling Berpengaruh di Indonesia, h. 113.

${ }^{40}$ Muhamadiyah lahir pada 18 November 1912 di Yogyakarta. Sebelum mendirikan Muhammadiyah, tahun 1911 Ahmad Dahlan terlebih dahulu mendirikan Sekolah Muhammadiyah sebagai salah satu pioner pendidikan modern yang berusaha mendobrak dikotomi ilmu agama dan ilmu umum yang ketika itu melanda dunia pendidikan di Indonesia Dalam Sekolah Muhammadiyah, selain diajarkan ilmu agama juga diajarkan ilmu-ilmu umum.

${ }^{41}$ NU lahir pada 31 Januari 1926 di Surabaya. Banyak pengamat menilai bahwa kelahiran NU merupakan kelanjutan atau perluasan dari Komite Hijaz yang dibentuk dengan dua tujuan yaitu untuk mengimbangi Komite Khilafat yang banyak didominasi kalangan modernis, dan untuk menyerukan kepada Raja Saudi Arabia, Ibnu Sa'ud agar mempertahankan praktik-praktik beragama sesuai tradisi. Lihat Deliar Noer, Gerakan Modern Islam di Indonesia, h. 242.
}

Selain dipengaruhi oleh pemikiran-pemikiran Ahmad Khatib alMinangkabawi yang tidak setuju dengan praktik-praktik tariqat karena dinilai tidak memiliki sandaran kepada Rasulullah SAW, pemikiran keagamaan Ahmad Dahlan banyak dipengaruhi oleh pemikiran Ibnu Taymiyyah, Muhammad Abduh dan Rasyid Ridha. Trio pembaharu ini menganjurkan umat Islam untuk membebaskan diri dari belenggu mazhab dan kembali kepada ajaran Islam yang murni yang sesuai dengan Al-Qur'an dan al-Hadith. Mereka menilai bahwa kemunduran umat Islam adalah karena adanya stagnasi, kebekuan dan kejumadan dalam berfikir. Dengan ungkapannya yang terkenal, al-Islâmu mahjûbun bi al-muslimîn (agama Islam tertutup kesempurnaannya oleh umat Islam sendiri), Abduh mengajak umat Muslimin untuk bangkit dan menggunakan rasionalitas dengan membuka pintu ijtihad seluas-luasnya. Karena Islam sangat memberikan penghargaan tinggi terhadap peran akal.

Oleh karena itulah, sejak lahirnya Muhammadiyah memproklamirkan dirinya sebagai gerakan non-mazhab dan non-tariqat. Di bidang keagamaan, Muhammadiyah langsung mengacu pada Al-Qur'an dan al-Hadith sesuai perintah QS Al-Nisa (4):59, “Jika kamu berselisih dalam suatu masalah, maka kembalikanlah kepada Allah dan RasulNya", ditambahkan dengan ijtihad ulama, sesuai dengan tuntunan Hadits, "Barang siapa melakukan ijtihad dan benar, maka baginya dua pahala, sedangkan bila salah dalam berijtihad, baginya satu pahala" (Al-Hadith). Kini KH Ahmad Dahlan telah meninggalkan warisan tak ternilai berupa organisasi Muhammadiyah kepada umat Islam Indonesia, yang hingga kini telah memiliki banyak amal usaha, baik di 
bidang pendidikan, sosial, kesehatan, ekonomi, budaya, dan sebagainya.

Sebagai ahli ilmu falak, kontribusi terbesar Ahmad Dahlan adalah membetulkan arah kiblat karena sebelumnnya masjid-masjid di Indonesia menghadap lurus ke barat. Sementara dalam perhitungan ilmu falak, kiblat sebenarnya menuju ka'bah seharusnya miring ke arah utara sekitar 24 derajat dari sebelah barat. Meski semula menuai banyak penolakan, ijtihad Ahmad Dahlan pada akhirnya berhasil meyakinkan para tokoh agama, dan kini masjid-masjid di Indonesia menghadap kiblat tidak lurus ke barat, melainkan miring ke arah utara sekitar 24 derajat dari sebelah barat.

Sementara itu, murid AlMinangkabawi yang lain, yaitu Hasyim Asy'ari juga meninggalkan warisan tak ternilai berupa organisasi NU. Berbeda dengan Muhammadiyah yang menyatakan sebagai organisasi nonmazhab dan non-tariqat, sejak kelahirannya. NU menyandarkan pemikiran keagamaannya pada pemikiran imam mazhab, khususnya Mazhab Syaf'i, dan sangat familiar dengan praktek dan ajaran tariqat, khususnya tariqat yang mu'tabarah. Bagi Hasyim Asy'ari, mempelajari ilmu-ilmu agama haruslah melalui pintu-pintunya, dan pintu-pintu ilmu agama adalah pendapat para imam mazhab.

Selain berperan dalam mencetak kader ulama dengan mendirikan salah satu pioner pesantren di Nusantara yaitu Pesantren Tebu Ireng di Jombang, dan meghasilkan banyak karya yang dijadikan pedoman bagi komunitas santri dan ulama, ${ }^{42}$ kontribusi terbesar

\footnotetext{
${ }^{42}$ Beberapa karya Hasyim Asy'ari antara lain Kitab Adab al-'Alim wa al-Muta'alim (perilaku guru dan murid), Al-Durâr alMuntatsiroh fi al-Masâil al-Tis' a 'Asyarah (taburan permata yang indah tentang semilan
}

Hasyim Asy'ari dan NU ada pada perannya sebagai organisasi pelestari tradisi. Jika bukan karena Komite Hijaz, yang akhirnya menjadi NU, pastilah umat Islam diseluruh dunia tidak akan pernah lagi bisa menyaksikan situs-situs bersejarah di Tanah Haramayn seperti makam Rasulullah SAW dan para sahabatnya. Ketika gerakan Wahabi pada tahun 1920-an berniat menghancurkan situs-situs ini dan hampir mendapatkan legitimasi dari penguasa Tanah Hijaz, Komite Hijaz lah yang berhasil meyakinkan penguasa Saudi Arabia untuk tidak melakukan upaya penghancuran tersebut. ${ }^{43}$

Masih banyak warisan Islam Nusantara yang lain. Tidak hanya berupa wujud budaya berupa material peradaban seperti ragam bangunan masjid, institusi berupa pesantren dan organisasi keagamaan yang hingga kini tetap kokoh berdiri, mushaf Al-Qur'an Nusantara dengan keunikan dan karakteristik lokalnya masing-masing, kitab-kitab maha karya para ulama yang bernilai tinggi, seni kaligrafi, penggunaan kalender hijriyah, ritual keagamaan yang berkolaborasi secara apik dengann tradisi semacam sekaten, slametan, dan sejenisnya, juga penggunaan bahasa agama (Arab) yang cukup familier untuk nama orang, tempat, maupun istilah-istilah kenegaraan dan sosial, dan sebagainya. Islam Nusantara juga mewariskan

\footnotetext{
belas perkara, membahas 19 masalah tariqat), al-Nûr al-Mubîn (cahaya penerang), dan sebagainya.

${ }^{43}$ Isu penghancuran makam Rasulullah SAW yang terletak di dalam Masjid Nabawi di Madinah beberapa kali terjadi sejak tahun 1960-an, 1990-an, dan yang termutakhir tanggal 3 September 2014 menyusul dipublikasikannya dokumen proposal pemugaran Masjid Nabawi oleh surat abar terbitan London, The Daily Mail. Pemerintah Arab Saudi melalui perwakilannya di Jakarta telah membantah isu tersebut.
} 
berbagai kearifan lokal yang lain. Penghormatan terhadap leluhur, norma agama dan tata nilai yang menjadi kesepakatan masyarakat, kelenturan dan kefleksibelan dalam menampilkan sikap dan keyakinan beragama, termasuk toleransi dengan tetap selektif terhadap hal-hal yang berasal dari budaya luar, serta ukhuwah Islamiyah yang dibungkus dengan egaliterianisme menjadi karakteristik yang melekat sebagai warisan Islam asli Nusantara.

\section{Penutup}

Di tengah situasi global dan arus ektremitas yang melanda sebagian negeri-negeri Muslim Timur Tengah (Arab Spring) yang berimbas pada luluh lantaknya situs-situs bersejarah warisan dunia Islam, ${ }^{44}$ umat Islam Indonesia patut bersyukur, bahwa meski bukan menjadi tanah asal turunnya agama mulia ini, berbagai warisan Islam masih terpelihara dengan baik. Kepiawaian para pendakwah dalam menyebarkan dan mengenalkan nilainilai Islam ke tengah-tengah masyarakat Nusantara dengan berbagai metode dan pendekatan, telah mengokohkan Nusantara (Indonesia) yang meskipun masyarakatnya sangat plural dan terdiri dari puluhan etnis, dengan ragam budaya, tradisi dan keyakinan sebagai negeri dengan komunitas Muslim

\footnotetext{
${ }^{44}$ Perhatikan betapa Baghdad yang pernah menjadi ibu kota Daulah Abbasiyah dan sempat menjadi jantung peradaban dunia pada masa klasik telah luluh lantak oleh invasi Amerika Serikat dan sikap ortodok umat Islam di sana yang masih mempertentangkan syiah-sunni. Demikian juga Suriah, di mana Damaskus pernah menjadi pusat kekuasaan Bani Umayyah, dan terakhir adalah Mesir, salah satu daerah gubernuran kekhalifahan Islam. Ribuan situs-situs bersejarah konon telah hancur akibat perang saudara di antara mereka.
}

terbesar di dunia yang memiliki beragam budaya.

Di tengah gempuran arus radikalisme dan liberalisme yang melanda sebagian dunia Islam, semoga warisan Islam Nusantara ini akan tetap terpelihara dengan baik, sehingga generasi penerus bisa terus menyaksikan dan mengabadikan peninggalan-peninggalan bersejarah ini. Warna moderatisme Islam Nusantara tidak hanya menjadi ekspektasi bagi kebangkitan Islam dunia, tetapi juga telah menjadi referensi bagi umat Muslim negeri lain tentang potret kehidupan beragama dan kehidupan sosial yang serasi, harmonis, akomodatif, dan ramah.

\section{Daftar Pustaka}

Abdul Baqir Zein, Masjid-Masjid Bersejarah di Indonesia, Jakarta: Gema Insani Press, 1999.

Azyumardi Azra, Jaringan Ulama Timur Tengah dan Kepulauan Nusantara Abad XVII-XVIII, Bandung: Mizan, 2004.

Bernard H.M. Viekke, Nusantara; A History of Indonesia (terj), (Jakarta: Gramedia, 2008

Deliar Noer, Gerakan Modern Islam di Indonesia, Jakarta: LP3ES, 1996.

Dirjen Pendis Depad RI, Post Tradisionalisme Islam; Wacana Intelektualisme dalam Komunitas NU, Jakarta: Dirjen Pendidikan Islam Depag RI, 2007.

GBPH H. Joyokusumo, Spiritual Islam dan Perspektif Budaya Jawa, dalam Aswab Mahasin dkk 
(ed), Ruh Islam dalam Budaya

Bangsa, Jakarta: Yayasan

Festifal Istiqlal, 1996.

Hasan Muarif Ambary, Menemukan Peradaban Arkeologi dan Islam di Indonesia Jakarta:Puslit Arkenas, 1998.

James Turner Johnson, The Holy War Idea in Western and Islamic Tradition (terj), Yogyakarta: Qalam, 1997.

John. L. Esposito, Islam and Politics, New York: Syracuse University, 1998

M.D. Mansoer, Sedjarah Minangkabau, Jakarta: Bhratara:, 1970.

Murodi, Melacak Asal-usul Gerakan Paderi di Sumatera Barat, Jakarta: Logos, 1999.

Mualimbunsu Syam Muhammad, Motivasi Perang Sabil di Nusantara, Jakarta: Media Madania, 2013.

Nurcholish Madjid, Islam Doktrin dan Peradaban, Jakarta: Paramadina, 2000.

Oman Fathurahman, "Tradisi Penulisan Kitab Hadis di Dunia MelayuNusantara; Tinjauan Khusus atas Hidayat al-Habib Karangan Nuruddin al-Raniri", makalah disampaikan dalam perkuliahan di Sekolah Pascasarjana mata kuliah History of Southeast Asian Islam; Social Intellectual, Selasa, 3 April 2012.

"Jaringan dengan Timur Tengah dan Menguatnya Diskursus Islam Berorientasi
Syariah", makalah disampaikan dalam perkuliahan di Sekolah Pascasarjana mata kuliah History of Southeast Asian Islam; Social Intellectual, Selasa, 17 April 2012.

Peter Carey, The Power of Prophecy; Prince Dipanegara and The End of an Old Order in Java, 17851855, Leiden: KITLV Press, 2007.

Sartono Kartodirdjo, Pengantar Sejarah Indonesia Baru 1500-1900, Jakarta: Gramedia Pustaka Utama, 1999.

Shalahuddin Hamid dan Iskandar Ahza, 100 Tokoh Islam paling Berpengaruh di Indonesia, Jakarta; Nusantara Lestari Ceriapratama, 2004. 
